\title{
THE PROLIFERATION OF NUCLEAR WEAPONS IN NORTH KOREA:
} INTERNATIONAL LAW PERSPECTIVE*

\author{
Yordan Gunawan ${ }^{1}$, Rima Ayu Andriana ${ }^{2}$ \\ Fakultas Hukum, Universitas Muhammadiyah Yogyakarta, Jl. Brawijaya, Tamantirto, \\ Kasihan, Bantul, Daerah Istimewa Yogyakarta \\ ${ }^{1}$ e-mail: yordangunawan@umy.ac.id \\ 2 e-mail: rima.ayu.2015@law.umy.ac.id
}

\begin{abstract}
The proliferation issue of nuclear weapons in North Korea is becoming a more serious problem to the international community. North Korea has been manufacturing and developing nuclear weapons technology, which receives many critics by the international community expressing that North Korea is being non-compliance with the Treaty on the Non-Proliferation of Nuclear Weapons (NPT) 1968. The criticism emerged following the North Korea withdrawal from the NPT 1968. Its withdrawal reasoning seems very hard to be justified after series of non-compliance behavior conducted by North Korea and the legitimacy of its withdrawal is being debated. By using normative legal research, the research aims to determine the status of North Korea upon its withdrawal from the NPT 1968 based on the withdrawal procedure that is required in the Article X of the NPT 1968. The result shows that North Korea is still a member and it is bound by the obligations contained in the Treaty and to make progress on a complete nuclear disarmament regime.
\end{abstract}

Keywords: Nuclear Weapon; NPT; North Korea.

\begin{abstract}
Abstrak
Program pengembangan senjata nuklir di Korea Utara terus menjadi masalah yang serius dan menjadi perdebatan komunitas internasional. Korea Utara dianggap masih memproduksi dan mengembangkan teknologi senjata nuklir tanpa memedulikan kritik dari komunitas internasional. Perbuatan Korea Utara semakin dikecam karena program tersebut menunjukkan ketidakpatuhan terhadap Perjanjian Non-Proliferasi Nuklir (NPT) 1968, yang telah ditandatangani. Tahun 2003, Korea Utara secara sepihak membuat pernyataan penarikan diri dari Perjanjian tersebut. Namun demikian, berdasarkan Pasal X NPT, dunia internasional menyebut bahwa alasan keluarnya Korea Utara dalam keikutsertaan sebagai negara anggota NPT sangat sulit untuk dibenarkan dan menjadi perdebatan serius dalam hal legalitas. Penelitian ini merupakan penelitian hukum normatif dan bertujuan untuk mengetahui legalitas keluarnya Korea Utara dari Perjanjian Non-Proliferasi Nuklir berdasarkan prosedur pengunduran diri yang diatur di dalam Pasal X NPT. Hasil penelitian menunjukkan bahwa Korea Utara tidak bisa secara sepihak menarik diri dari NPT dan masih menjadi anggota dari Perjanjian tersebut. Korea Utara juga masih terikat terhadap kewajibankewajiban sebagaimana tercantum dari Perjanjian, terutama melakukan program pelucutan senjata nuklir yang diwajibkan untuk semua negara anggota di dunia.
\end{abstract}

Keywords: Senjata Nuklir; NPT; Korea Utara.

\footnotetext{
* Naskah diterima: 11 Juli 2019, direvisi: 17 Agustus 2019, disetujui untuk terbit: 30 September 2019 Doi: $10.3376 /$ jch.v5i1.162
} 


\section{INTRODUCTION}

A summit between the leaders of the United States and North Korea, Donald Trump and Kim Jong-Un, was held recently in February in Hanoi, Viet Nam. The summit was the second United States-North Korea summit after the first summit that was held back in June 2018 in Singapore. The leaders are in for talks on nuclear disarmament.

Several talks have been done by the United States and the international community to negotiate with North Korea's regarding its nuclear and missile development and the export of nuclear missile technology. Despite these efforts, numerous reports saying that Kim's administration continues to advance its nuclear and ballistic missile program with the ongoing rockets, warheads, and fissile production. These reports put North Korea as a nuclear threat to the global nuclear nonproliferation regime.

All diplomatic efforts done by the United States and the international community was for denuclearization in North Korea when North Korea intended to withdraw from the nuclear NonProliferation Treaty 1968 (NPT). The International Atomic Energy Agency (IAEA) was allowing North Korea to draw out its obligation to be inspected thoroughly by IAEA within 18 months after signing and ratifying the NPT (Sokolski, 2010: 420). IAEA role in carrying out an inspection did not start until 1992, and yet during that time, North Korea had illicitly separated plutonium. When IAEA requested an inspection of two nuclear waste sites, North Korea refused and submitted their withdrawal from the NPT (Huntley, 2006: 724).

The Tensions between North Korea with the United States and advocates of NPT until mid-1994 that eased with the Agreed Framework concluded by the U.S and North Korea, which froze North Korea's plutonium-based nuclear power program. In 2002, reports said that North Korea was doing a second, uranium-based nuclear program which triggered the Agreed Framework crumbling and culminating North Korea withdrew from the NPT.

International community questioned the legality of this action and the justification of North Korea reason to withdraw from the NPT as it is considered as a step that was not legitimate by the world community (Bunn \& Timerbaev, 2005: 23). Even though North Korea withdrawal was within the legal stipulation under article X of NPT, its withdrawal from the NPT do not change the fact that North Korea had committed a breach toward its obligations under the NPT by operating its uranium-enrichment program when the NPT was in force and its withdrawal far from "good faith" principle of international criteria.

Upon its withdrawal from the NPT, North Korea stated that it does not have any intention on making nuclear weapons and their activities will be confined to energy power production and other peaceful purposes. However, in 2005, North Korea officially stated that it has nuclear weapons and have conducted 
Yordan Gunawan dan Rima Ayu Andriana: The Proliferation Of Nuclear Weapons In...

nuclear test clarifying their action as part of regular military train for self-defense. It is a clear cut that North Korea withdrawal from NPT was to get away from their obligation.

These series of reasoning that it may be concluded that the arguments given out by North Korea in justifying its withdrawal from NPT are difficult to be conciliating with the application of the extraordinary events clause contained in Article X. The academic debate on the legitimacy of North Korea withdrawal from NPT whether its withdrawal is legitimate under international law. Based on the background above, the author considers analyzing the proliferation of nuclear weapons in North Korea from an international law perspective.

\section{RESEARCH METHOD}

The types of this research are under normative research method especially related to the issue of the proliferation of nuclear weapon under International Law. Normative Legal Research is a research in the form of prevailing law inventories by seeking principles or the basic philosophy of the legislation, or a research for the legal discovery purpose of any particular case (Soekanto \& Mamudji, 2007: 12).

Moreover, In connection with the normative legal research, the author uses a statutory approach and case approach. The statutory approach is conducted by highlighting some regulations that related to the issues while case approach is conducted by reviewing the case that related to the issues. Statutory approach means that the author highlights some legislation or regulation as the basic for conducting the research that related to the issues while case approach is conducted by reviewing the case that related to the issue (Marzuki, 2008: 86).

The author collected the data from library, focusing on a reading and analysis of the primary and secondary materials (such as legal dictionaries, textbooks, journal articles, case digests and legal encyclopedias).

This research uses secondary data that consist of primary legal secondary legal material and tertiary legal materials. Treaty on the Non-Proliferation of Nuclear Weapons 1968 is used as a primary legal material while the secondary legal material used scientific journals, books, papers or any document related to the issue.

The method of collecting data in this research will be done through library research by literature learning. This method collects the data from read, write, analyze, and gather information related to the topic of this thesis. After having information from the documents such as international and national legal instrument, book, journal, and others related to the main problem as the main of this research, author ultimately tries to create conclusion.

The data were analyzed systematically through juridical qualitative approach. Systematically through evaluative, where the data was taken relating to the issues to be 
researched. Juridical qualitative means that it would be connected with the principle of law, convention, and other regulation. So that can be systematic,

qualitative and comprehensive, illustrating the facts that are valid and related to prevailing law.

\section{RESULT AND ANALYSIS}

\section{A. History of North Korea and the \\ Nuclear Weapons Program}

North Korea and its nuclear weapons program can be traced back from early of the 1950s. A nuclear research institution was established in 1952 by the North Korea government called as the Atomic Energy Research Institute but the research just began after North Korea established an agreement with the USSR (Moltz \& Mansourov, 2000: 17). North Korea signed an agreement in 1956 on nuclear research with USSR and not long after that, scientists from North Korea along with scientists from People's Republic of China (PRC) arrived in Dubna Joint Institute for Nuclear Research that located in central Russia to be trained and introduced to a nuclear power program (Clemens, 2010: 129).

In September 1959, North Korea and the Soviet Union signed an agreement on peaceful uses of nuclear energy. In the agreement, it provided a provision that stated the Soviets to assist North Korea in establishing a nuclear research center that will be located on the bank of Kuryong River approximately eight kilometers from the center of Yongbyon town. The Soviets provided large technical assistance such as the installation of a Soviet IRT-2000 nuclear research reactor and the Soviets engineer took part in the construction of the reactor which became operational in 1965. Even though in the early stage on the development of the North Korea nuclear program was assisted and influenced by the Soviet Union and China, it continues to be developed without any significance assistance from foreign countries. ThenNorth Korean leader Kim Il Sung possessed ultimate control of nuclear program and decision making related to weapons development.

Following China's nuclear test in October 1964, Kim Il Sung asked Chinese leader, Mao Tse-tung, to share its nuclear weapons technology and help North Korea in developing nuclear weapons but the Koreans were sent back empty-handed (Bermudez, Jr., 1991: 409). The relationship between North Korea and China became estranged. A year after that, however, the Soviet Union sold a small two- to four- megawatt research reactor to North Korea and later built in the Yongbyon neighborhood which began to operate in 1967.

North Korea has received assistance and aid from foreign countries and they started to demand more. North Korea began to request for a delivery of a nuclear power plant to the Soviets but was rejected. The reason behind the Soviets rejection was explained in the note report of the Embassy of Hungary in North Korea to the Hungarian Foreign Ministry. The Soviet rejected the North Korean 
Yordan Gunawan dan Rima Ayu Andriana: The Proliferation Of Nuclear Weapons In...

leader request as the nuclear reactor that had been provided and established in Korea with Soviet assistance was operated since approximately one and a half years ago but there were hardly any data about its operation received by the Soviet comrades.

There was conflict across the globe that happened in 1968. One of the events that occurred was an attacked done by North Korea against the Republic of Korea president's Blue House in Seoul and protested US aggression by seized an unarmed US spy ship, the Pueblo. The Soviets instructed North Korea to return the US crew and the latter did not comply with the instruction. Kim Il Sung called out on the Soviet Union to honor their partnership but was refused by Leonid Brezhnev, then-Soviet Union leader, and call for them to Moscow. This creates tensions between North Korea and Soviet leaders.

The United States and USSR as the co-author who drafted the Treaty on the Non-Proliferation of Nuclear Weapons (NPT) submitted to all of the UN members for signature in 1968 (Quester, 1972: 1) and that increase the tensions between North Korea and the Soviets. The USSR turns out stood ready to provide nuclear power assistance only to clients who were both loyal and advanced enough to deal with a nuclear technology such as Bulgaria, Czechoslovakia, the GDR, and Hungary. Romania and North Korea considered to be defiant so they were excluded and so was Viet Nam; they were obedient but not ready for advanced technology.

Romania made a visit to Pyongyang in February 1968 which both countries agreed that "small countries would also be able to use atomic energy on peaceful uses and that should be ensured by the big countries possessed the nuclear capacity." (Report, 1968). Many objections were made towards the NPT in 1968 but Romania signed the treaty eventually and submitted to the safeguards. However, North Korea refused to sign the NPT and called off its safeguard agreement with IAEA.

By the early 1970s, North Korea engineer used their own technology to expand the IRT-2000 research reactor and they also acquired the plutonium reprocessing technology from the Soviets. July 1977, North Korea signed a facilityspecific safeguard agreement with the International Atomic Energy Agency together with the Soviet Union. The Soviets was included in the agreement as they were the one who supplied not only the IRT-2000 research reactor but also the reactor fuel.

In the early 1980s, there was a significant expansion done by the North Korea engineers where a uranium milling facilities, a fuel rod fabrication complex, and a $5 \mathrm{MW}(\mathrm{e})$ nuclear reactor was built. They started to do the experiment test on the high explosive for the nuclear bomb triggering mechanism. Not only that, North Korea had begun building the 50MW(e) nuclear reactor in Yongbyon Nuclear Research Center and began to do 
some expansion to the uranium enrichment facilities.

The exploration by North Korea did not stop there. They also did some exploration on the light water reactor technology in the early to mid-1980s. This period also consists of the expansion of the reactor program. The reactor program was designed and construed indigenously by North Korea, which was designed based on the prototype 25MW carbon dioxide-cooled, graphitemoderated reactor and became operational in 1986 (Braun, 2016: 4)

On 12 December 1985, North Korea joined the NPT as a non-nuclear-weapon State (NNWS) (Ahlström, 2004: 770). Accordingly, North Korea is under the regulation of the NPT and have to comply all the rights and obligations as an NNWS. NNWS must pursue in good faith the three pillars of the NPT, which are non-proliferation, the peaceful use of nuclear energy, and disarmament.

In the early 1990s, Then-President of United States, George H. W. Bush, announced that the United States would withdraw their nuclear weapons from South Korea in September 1991 and on 18 December 1991, South Korea President, Roh Taw Woo, declared that South Korea was free from nuclear weapons (Kristensen \& Norris, 2017: 352). Following that event, the Joint Declaration on the Denuclearization of the Korean Peninsula between North Korea and South Korea was signed. Under the Joint Declaration, both North Korea and South Korea agree: a. Not to test, manufacture, produce, receive, possess, store, deploy;

b. Not to use nuclear weapons;

c. To use nuclear energy only for peaceful purposes;

d. Not to possess facilities for nuclear reprocessing and uranium enrichment(“Joint Declaration of South and North Korea on the Denuclearization of the Korean Peninsula | Treaties \& Regimes | NTI,").

This agreement bound the two countries to give up their possession of nuclear and uranium enrichment facilities and the joint declaration also provided a bilateral inspection regime, but an agreement on its implementation was never successful.

\section{B. North Korea First Withdrawal from the NPT}

In 30 January 1992, North Korea agreed to a full safeguards agreement with the IAEA based on Article III of the NPT and agreed to delay the operation the 1977 agreement, and North Korea government ratified the agreement on 9 April 1992. The full safeguard agreement entered into force on 10 April 1992. Based on the term contain in this agreement, it required North Korea to submit an initial declaration of its nuclear materials and facilities and also to give IAEA inspectors permission on access to verify the validity of the declaration (Fischer, 1997: 289).

Six rounds of inspections were conducted which began in May 1992 and 
Yordan Gunawan dan Rima Ayu Andriana: The Proliferation Of Nuclear Weapons In...

concluded in February 1993. The DPRK submitted the initial report on 4 May 1992 to the IAEA under the agreement. Under IAEA safeguards in 1977, they are only aware on the existence of research reactor supplied by the Soviets. North Korea in the Initial Report listed:

a. $5 \mathrm{MW}(\mathrm{e})$ graphite in the type of Magnox;

b. Plant fuel fabrication;

c. radiochemical laboratory;

d. Two larger Magnox type reactors of 50 MW(e) and 200 MW(e) under construction.

North Korea itself had indigenously built the three Magnox reactors. The reactors were built based on similar plutonium-based reactors used by Britain in 1950 s to produce warhead and to generate it first nuclear electricity. The 50 MW(e) reactor was scheduled to be finished by North Korea in 1995. 40-50 kilograms of plutonium would have been able to be produced by the reactor in a year which enough for producing five to ten nuclear warheads.

In the Initial Report, North Korea showed a small amount of plutonium (less than 100 grams) that they stated that it was coming from the extraction of damaged fuel rods discharged from the 5 MW(e) reactor. North Korea persistently maintained that they only possess a small amount of plutonium that had separated and they had only conducted a one-time reprocessing operation in 1990. However, IAEA analysis result showed that there had been more than one-time reprocessing activity (Fischer, 1997: 289). Inconsistent with the Initial Report, indicating the existence of undeclared plutonium and the findings of IAEA (Albright, 2015). Whether the undeclared plutonium amount to grams or kilograms can only be made sure after further investigation and more exploration to the reactor or not. The waste analysis given by the DPRK to the IAEA shows the inconsistencies between that and plutonium presented by the DPRK.

Meanwhile, satellite images were provided by the United States satellite to the IAEA and showed two constructions had not been listed in the initial report submitted by North Korea. It is clear that North Korea had tried to disguise the two constructions using that planting trees and other camouflage as it showed in the satellite images. Then, the IAEA requested access to additional information and to two sites in order to verify the validity of the initial report, whether it is complete or not. However, IAEA request to access the two sites were refused by North Korea. The ground of the refusal was that the two sites were military installations.

After rejection to the IAEA get access, in April 1993 the IAEA Board of Governors concluded that the DPRK was being non-compliance with the IAEADPRK safeguards agreement and referred to this non-compliance to the UN Security Council. In May 1993 the Security Council adopted Resolution 825 by a vote of 13 in favor, with China and Pakistan abstaining, calling upon the DPRK to comply with its safeguard's agreement, 
two but it was not successful. The special inspection did not take place (Vyas, Chen, Roy, \& East-West Center, 2015: 21). On March 12, 1993 North Korea reaction to the IAEA's request for a special inspection, announced its decision to withdraw from the NPT under Article X. In Article X Paragraph 1 of NPT stated that:

"Each Party shall exercise its national sovereignty has the right to withdraw from the Treaty if it decides that extraordinary events, related to the subject matter of this Treaty, have jeopardized the supreme interests of its country. It must be noticed to all other United Nations Security Councils three months in advance. Such notice should include a statement of the extraordinary event as having jeopardized its supreme interests."(NPT 1968: Art. X).

Under the provision of the treaty, the withdrawal from a state does not take effect until 90 days after it has given notice. On 11 June 1993, one day before North Korea notice of withdrawal from the NPT was to have come into effect, DPRK stated in the Joint Statement with the USA that it had "decided unilaterally to suspend as long as it was deemed necessary to withdraw from the Nuclear

Weapons Non-Proliferation Treaty effectively." North Korea also accepts IAEA regular inspection on the sites that North Korea had declared in its Initial Report (IAEA Report, 2011: 3).

In the case of North Korea In 1993, North Korea announced its withdrawal from the NPT after IAEA request for special inspection on several nuclear sites rejected by North Korea. The withdrawal was within Article X Paragraph 1 of NPT, where an extraordinary event has jeopardized the supreme interest of North Korea. An extraordinary event happened because of the request by IAEA to inspect several nuclear sites that could threaten its sovereignty as an independent state.

\section{Crisis in 1994 and the Agreed Framework}

In 1994, the IAEA suggested that when the irradiated fuel from the $5 \mathrm{MW}(\mathrm{e})$ reactor will be discharged, it should be discharged in a way that IAEA permit so they could verify the history of the reactor core activity. It will also help to solve the question of whether North Korea had separated more plutonium than what they had declared in its Initial Report or not.

In May 1994, North Korea rejected IAEA's proposal and carelessly discharged the fuel in a way that is not approved by IAEA as to make any historical analysis of the core will be impossible to track (Dembinski, 1995: 35). On 10 June 1994, IAEA Board of Governors decided to suspend all IAEA technical assistance in North Korea. North Korea responded on 13 June by announcing its withdrawal from the Agency. On 16 June 1994, the United States proposed that the Security Council should impose a series of more severe sanctions on North Korea. The action of the United States was responded by North Korea saying that sanctions would mean war. The USA declared that threats would not discourage it. This event causes a 
Yordan Gunawan dan Rima Ayu Andriana: The Proliferation Of Nuclear Weapons In...

crisis as a war might break out between the United States and North Korea.

After the tension culminated, on 17 June 1994 the former President Jimmy Carter stepped in and went to Pyongyang to discuss the crisis with Kim Il Sung himself and Carter managed to come back with a conciliatory message (Litwak \& Woodrow Wilson International Center for Scholars, 2017). If the USA was prepared to meet North Korea on certain points (e.g., diplomatic recognition, an assurance that the USA would not attack North Korea and access to US nuclear power technology), North Korea would be prepared to refrain from refueling the operating reactor and to refrain from reprocessing the spent fuel, perhaps stop the construction of the larger reactors, and allow the IAEA to keep its inspectors in the North Korea.

The US barely responded to this suggestion by continuing high-level discussions with the Government of the DPRK despite the death of Kim Il-Sung and the allegedly unresolved power struggle in Pyongyang. On 5 August 1994, 'high-level talks' reopened in Geneva and on 18 October the two delegations announced that they had been able to conclude in a so-called "Agreed Framework," which they signed three days later on 21 October 1994. On 4 November 1994, the Security Council asked the IAEA to carry out the tasks assigned to it in the "Agreed Framework" and on 11 November 1994, the IAEA Board authorized the Director-General to do so. Under the Agreed Framework: a. North Korea would freeze its existing nuclear program and accept international verification of all existing plants;

b. The IAEA would verify compliance with the freeze and would continue to inspect unfrozen activities;

c. North Korea would eventually dismantle all the frozen plants;

d. The two governments would seek methods of storing the fuel from the 5 MW(e) reactor and disposing of it in a way that does not involve reprocessing in the North Korea;

e. The USA would put together an international agreement to arrange financing the supply of two 1000 MW(e) light water reactors;

f. Dismantling of the North Korea's plants would be completed when the LWR project is completed;

g. The USA would arrange for the supply of heavy oil to offset the energy foregone due to the freeze of the North Korea graphite-moderated reactors;

h. Both nations would loosen the trade restrictions and move toward establishing diplomatic relations;

i. The USA would give formal assurances to North Korea against the threat of use of nuclear weapons by the USA;

j. Steps will be taken by North Korea to implement the North-South Korean agreement on denuclearizing the peninsula;

k. North Korea would remain party to the NPT and would allow implementation of its safeguards 
agreement under the Treaty; significant portion of the light water reactor project was completed, but before delivery of key nuclear components, North Korea will come into full compliance with its safeguards agreement, including taking all steps that may be deemed necessary by the IAEA, following consultations with the Agency with regard to verifying the accuracy and completeness of the Initial Report on all nuclear material in the It should also be noted there was no mention in the Agreed Framework that North Korea rejoining the IAEA.

After the conclusion of 1994 Agreed Framework, the United States together with South Korea and Japan agreed to establish the Korean Peninsula Energy Development Organization (KEDO) in order to implement the 1994 Agreed Framework in March 1995. KEDO would supervise the financing and construction of light-water reactors to replace the existing North Korea's graphitemoderator reactors (Pollack, 2003: 10). North Korea and KEDO signed the contract for two LWRs in December 1995 with completion target date of LWRs project on 2003.

Based on the 1994 Agreed Framework, North Korea agreed to freeze their existing nuclear programs and accept inspection on 'unfrozen' plants and eventually dismantle their 'frozen' plants. Another highlight from the Agreed Framework is that North Korea would remain as a party to the NPT in exchange for Light-Water Reactor (LWR).

LWR, commonly used reactors in nuclear power plants, were mentioned in the Agreed Framework. North Korea was demanding for the completion of LWR in exchange for the implementation of IAEA safeguard to be allowed. LWR is very needed by North Korea as they have been facing energy and electricity shortage for over a decade and resulted in the development of its economic constrained (Zhang, 2006: 3.).

Two main primary resources relied on by North Korea in the early 2000s is coal and hydropower. Coal resource in North Korea is minimal and recoverable reserved coal used as a fuel in coal-fired power generation only supply generator for about ten years. However, the coal generator has decreased that was caused by flood and hydropower is also damaged by the flood. North Korea realized as they are gradually losing its primary energy, they need to ensure security energy in the future by exploring and developing nuclear power plants based on another energy resource, which is uranium.

North Korea has plenty of natural uranium which could be used as a fuel to supply its electricity generator for hundreds of years (Zhang, 2006: 3). They reported having known natural uranium around 300,000 Megaton which estimated could supply nuclear power generator for around 250 years if they manage to process the natural uranium so that it can be used. That is why LWR is very 
Yordan Gunawan dan Rima Ayu Andriana: The Proliferation Of Nuclear Weapons In...

important for North Korea to acquire in order to process natural uranium.

The discovery of the U.S intelligence on North Korea attempt in acquiring materials and equipment for the construction of their enrich facility in early of 2000s violated the value of 1994 Agreed Framework which both states, the United States and North Korea, pledge to keep the Korean Peninsula free from nuclear weapons and to normalize both of their political and economic relations. This violation resulted in the breakdown of the Agreed Framework.

North Korea is a non-nuclear-weapon state (NNWS) which based on NPT, NNWS nuclear activities shall only serve to peaceful purposes and shall be verified by the IAEA Safeguards system. Not only in NPT, based on 1992 Joint Declaration between North Korea and South Korea where North Korea agreed that their nuclear activities will only for peaceful purposes and requires them not to possess any facilities for nuclear reprocessing and uranium enrichment which could lead to manufacturing of nuclear weapons.

North Korea has been found trying to build an enrichment facility to enrich their uranium while it is still a part of NPT as an NNWS and is under obligation conferred by NPT. An NNWS has the right to the peaceful use of nuclear energy for the benefit in doing research, production and uses the nuclear energy which is a right that is unable to be taken away from States parties to NPT and protected under Article IV of NPT. However, the right has to be in full conformity with their non-proliferation obligation as a non-nuclear-weapon States. Accepting IAEA safeguards system is an obligation that every NNWS must comply based on Article III of NPT in order to prevent any diversion from peaceful uses of nuclear energy to manufacturing or to acquire nuclear weapons or any nuclear explosive devices. By the discovery that North Korea were trying to use the nuclear energy to be nuclear weapon, they were not in good faith with the NPT and the Agreed Framework. It is proven that North Korea being non-compliance with its obligation contain in NPT.

In summer 2002, U.S. intelligence report that they discovered evidence of Highly Enrichment Uranium (HEU) technology or materials transfers from Pakistan to North Korea in exchange for ballistic missile technology. It was discovered that there were black-market nuclear activities of Pakistani nuclear scientist, Abdul Qadeer Khan, who confronted North Korea the alternative way to acquire nuclear weapons. $\mathrm{He}$ deliberately proliferated nuclear weapons technology for the profit where he transferred centrifuges, oils, and the instruction on centrifuge technology (Nikitin, 2013: 9). The centrifuge was materials that are going to be used for the construction of the gas-centrifuge enrichment facility by North Korea. Around that time, North Korea started to build the secret facility of uranium enrichment at Kangson which located in the outskirts of Pyongyang. 
After the confrontation made by the United States to the DPRK's secret uranium enrichment facility, the Bush Administration called upon the North Korea to stop their secret uranium enrichment facility and put pressure to the North Korea by passing a Resolution through KEDO that contain the suspension on heavy oil shipment and suspension of light water reactors construction in 2002. North Korea reacted to the pressure by taking a hostile move which is to restart its nuclear program that was shut down under the Agreed Framework in 1994. IAEA officials were also expelled from DPRK who had been keeping under surveillance the plutonium facilities (Niksch, 2005: 3).

The dispute culminated on January 2003 when North Korea announced its withdrawal from the NPT. North Korea announced instant effectuation on their withdrawal from the NPT and they threatened to end their moratorium on long-range missile test applied since 1999. After the withdrawal, North Korea also declared that they are free from any restriction of the safeguard agreement with the IAEA.

North Korea North Korea announced its withdrawal again from the NPT but with immediate effectuation of their withdrawal because North Korea argued that they had fulfilled the NPT's threemonth notice. North Korea insists on their stance that because their 1993 withdrawal was suspended on days 89 , one day before their withdrawal took in effect, so their withdrawal in 2003 will take in effect one day after the announcement as a form of continuation. North Korea procedure to withdraw from the NPT in 2003 did not fulfill the requirement contained in Article $X$ Paragraph 1 of NPT. Therefore, the withdrawal could not be determined as legitimate. However, with the absence of any action by the United Nations Security Council upon North Korea withdrawal in 2003, North Korea withdrawal considered justified.

\section{Six-Party Talks as a Diplomatic \\ Measures}

The first round of Six-Party Talks began in August 2003 which involving several states such as Japan, People's Republic of China, the Russian Federation, the United States, the Republic of Korea, and the DPRK itself. These talks aimed to find a peaceful resolution regarding security in the Korean peninsula region because of the nuclear weapons program in North Korea. The first round of Six-Party Talks took place in Beijing on August 27, 2003 where North Korea demands a normalization of relations with the United States. At the end of the talks, parties involved agreed to commit to resolving nuclear issue by peaceful means and dialogue, taking the security concern of DPRK into consideration, and stay away from any action that could aggravate the situation in the process of negotiations ("Six-Point Consensus Reached at Sixparty Talks: Chinese Vice FM,”).

The second round of talks was held on February 2004 in Beijing. The second round was focused on how to resolve the 
Yordan Gunawan dan Rima Ayu Andriana: The Proliferation Of Nuclear Weapons In...

nuclear issue and how North Korea should denuclearize. The Chairman's Statement, the Six-Party Talks written document, was issued in which the parties agreed to resolve the nuclear issues through dialogue peacefully, wished for coexistence between participating parties, and emphasizing on the of mutually coordinated measures

The talks continue to the third round on June 23 to 26 in the same year the second round was held. In the third round of the Talks, North Korea stated that a 'freeze' on their nuclear program would be the last step of denuclearization; whiles the U.S. proposed that denuclearization need to be done periodically. The United States proposes that North Korea will be given three months to prepare freezing on its nuclear program and to submit a report North Korea full activities in their nuclear program. A sufficient consensus did not reach for a Joint Statement in this round, but the commitment was made to resolve the issue.

The Talks from the third round to the fourth round had it breaks for a year. The breaks caused by the Presidential Election in the U.S. and North Korea wanted to wait for the confirmation of Bush second administration before they decided to attend the talks. However, in early February 2005, North Korea announced that they possessed nuclear weapons and would not attend any six-party talks. They accused the United States wanted to overthrow North Korea government. In July 2005, after a meeting with the U.S. lead negotiator, Christopher Hill, North
Korea announced that they would attend another round of Six-Party Talks. One of the reasons why North Korea was willing to be back on Six-Party Talks was because of United States stated that they recognize North Korea as a sovereign state and the United States do not have any intention to invade North Korea.

After some coordination, the fourth round of Six-Party Talks was held in Beijing and was divided into two phases, 26 July to 7 August and 13 September to 19 September. The process was very long but it produced a very successful result. A Joint Statement was finally made between the parties. The highlight of the Joint Statement was North Korea pledged itself to abandon their nuclear programs and all its nuclear weapon, return to the NPT and would receive IAEA inspection, and their right of peaceful uses of nuclear energy to be respected by other parties. Unfortunately, the positive result from the previous round did not last long. Once more, North Korea banned the Six-Party Talks after the U.S. imposed economic sanctions to them following the accusation made by the U.S. that Banco Delta Asia (BDA), a Macau-based bank, had money laundering bank notes from some of the North Korean accounts (M.

B. D. Nikitin, Chanlett-Avery, \& Manyin, 2017: 8).

Following the sanction imposed by the United States, North Korea conducted its very first nuclear missile test in 2006 which received many condemn from another state. UN Security Council passed its 1718 Resolution that prohibits North 
Korea from conducting future nuclear tests or launch a ballistic missile and calls them to stop any of their activity in developing nuclear weapons. The Resolution banned exports and imports in for of any military weapons and equipment, and UNSC freezes the asset of North Korea and a travel ban on people and entities tied to the nuclear program.

Another round of talks resumed in February 2007 in which an agreement was made to execute the Joint Statement. In the agreement, North Korea pledged to shut down their nuclear facilities and to declare every activity related to nuclear, and in exchange for that, North Korea will be provided tons of heavy fuel oil and removed from the list of state sponsors of terrorism. The other parties have committed themselves to help North Korea by providing energy assistance. IAEA officers will also be returned to North Korea to inspect and monitor the facilities at Yongbyon which their presence was there until mid-April 2009.

In the sixth round, it was confirmed by IAEA officials that the nuclear reactor in Yongbyon had been shut and sealed in July 2007 and the United States announced that North Korea had been removed from the list of the state which sponsors terrorism. On 5 April 2009, North Korea launched its first satellite which was condemned by the UN Security Council and the action was considered to violate UNSC Resolution 1718. The UN Security Council agreed to expand the sanctions on North Korea which responded by North Korea that the
Joint Statement and the Talks would no longer bound them.

After the conduct of nuclear missile test in 2006 and 2009, North Korea had conducted another nuclear test and satellite launch. The UN Security Council had issued several Resolutions to North Korea:

1. The second Resolution issued in 2009, where they imposed further sanctions on North Korea was included in Resolution 1874 in response to the second nuclear test, conducted in May 2009. The Resolution imposes a restriction to North Korea in developing nuclear weapons program and also tightens sanctions on nuclear weapons development programs and tightens sanctions on further goods, such as all imports and exports of weapons, and also to additional persons and entities that have a relation with the nuclear program. Financial transaction, transfer or loan that could be used to help the development of nuclear weapons or ballistic missiles is also prohibited. States are required to do an inspection and detain any cargo coming to or from North Korea through their territory on land, sea, or air if the cargo is suspected of being used to develop nuclear.

2. In December 2012, North Korea successfully launched its satellite which received condemnation from many countries. On January 2013, the UN Security Council passed 2087 Resolution by strengthening the 
Yordan Gunawan dan Rima Ayu Andriana: The Proliferation Of Nuclear Weapons In...

previous sanctions and calling for states again to do inspection on North Korean cargo passing through their territory.

3. Resolution 2094 was issued after another nuclear test was conducted by North Korea continue in February 2013 where UN Security Council adopted the Resolution condemns the test and strengthen existing sanctions given to the North Korea. Another target of the Resolution is denying big amount of cash transfer into North Korea and calling for sanction to any bank account that related to the North Korea nuclear program.

4. Resolution 2270 was passed in 2016 after North Korea nuclear and missile test which include inspection of all cargo passing to and from North Korea and prohibition of all trade on nuclear weapons. Additional to that, restriction on North Korean imports of luxury goods.

5. In response to North Korea missile test on July 2017, Resolution 2375 was adopted by UN Security Council. The Resolution imposed oil sanctions against the North Korea by reducing level of oil barrel exports from 4 million barrels to 2 million barrels per year. It also applied to exports of refined petroleum products. The Resolution bans the North Korean textile also restrict the country's workers export.

In North Korea's case, the proliferation of nuclear weapons is illegitimate as their status under the NPT is still a member and their obligation not to acquire or manufacture nuclear weapons. As in the result on the fourth round of Six-Party Talks, North Korea agreed to return to the NPT and must comply with its entire obligation. North Korea is not directly withdraw from the NPT because of the decision made is not a multilateral decision while the Talks itself is a multilateral agreement. There was never any official withdrawal made by North Korea after returning the NPT where a withdrawal from the treaty must be recognized by other States. Therefore, North Korea is still part of NPT and still bound by the obligation contain in NPT. In conclusion, North Korea is not allowed to develop any nuclear technology, expose all of the nuclear facility, and eventually undertake a complete nuclear disarmament.

\section{CONCLUSION}

Despite the fact that North Korea has declared the withdrawal from the NPT in 2003, North Korea is still a member of the treaty. As in Article X of NPT stated that a withdrawal from the treaty must be notified to other members and the United Nations Security Council, which never did by North Korea. Therefore, North Korea has the same rights and obligations with other members of the NPT and to make progress on disarmament obligations by ceasing activity in developing nuclear weapons and complete nuclear disarmament.

\section{REFERENCES}

\section{Books and Journals:}


Ahlström, Christer 2004, "Withdrawal from Arms Control Treaties", SIPRI Yearbook 2004, Oxford, Oxford University Press.

Bermudez, Jr., Joseph S. 1991, "North Korea's Nuclear Programme", Jane's Intelligence Review, Vol. 3, No. 9, London, IHS Markit.

Braun, Chaim. 2016, "North Korean Nuclear Facilities After the Agreed Framework", Center for International Security and Cooperation, Standford, Standford University.

Bunn, George and Roland Timerbaev. 2005, "The Right to Withdraw From the Nuclear Non-proliferation Treaty (NPT): The Views of Two NPT Negotiators", Yaderny Kontrol, Vol. 10, No. 1-2, Russia, PIR Center.

Clemens Jr, Walter C. 2010, "North Korea's Quest for Nuclear Weapons: New Historical Evidence", Journal of East Studies, Vol. 10, No. 1, Cambridge, Cambridge University Press.

Dembinski, Matthias. 1995, "North Korea, International Atomic Energy Agency, Special Inspections, and the Future of the Nonproliferation Regime", The Nonproliferation Review, Vol. 2, No. 2, United States, James Martin Center for Nonproliferation Studies.

Fischer, David. 1997, History of International Atomic Energy Agency: the First Forty Years,

Vienna, International Atomic Energy Agency.
Huntley, Wade L. 2006, "Rebel without a Cause: North Korea, Iran and the NPT", International Affairs, Vol. 82, No. 4, London, The Royal Institute of International Affairs.

Kristensen, Hans M. 2017, "A History of US Nuclear Weapons in South Korea", Bulletin of the Atomic Scientists, United States, Routledge:

Taylor \& Francis Group.

Litwak, Robert S. 2017, "Preventing North Korea's Nuclear Breakout", Woodrow Wilson International Center for Scholars, Washington, Wilson Center.

Marzuki, Peter Mahmud. 2011, Penelitian Hukum, Jakarta, Kencana Prenada Media Group.

Moltz, James Clay and Alexandre Y. Mansourov. 2000, The North Korean Nuclear Program: Security, Strategy, and New Perspectives, New York, Routledge.

Nikitin, Mary Beth D. 2013, "North Korea's Nuclear Weapons: Technical Issues", Congressional Research Service, Washington, Library of Congress.

Niksch, Larry A. 2005, "U.S.-Korean Relations-Issues for Congress", Congressional Research Service, Washington, Library of Congress.

Pollack, Jonathan D. 2003, "The United States, North Korea, and the End of the Agreed Framework", Naval War College Review, Vol. 56, No. 3, Newport, U.S. Naval War College Press.

Quester, George H. 1972, “Soviet Policy on the Nuclear Non-Proliferation 
Yordan Gunawan dan Rima Ayu Andriana: The Proliferation Of Nuclear Weapons In...

Treaty", Cornell International Law

Journal, Vol. 5, No. 1, New York,

Cornell University Law Library.

Soekanto, Soerjono \& Sri Mamudji. 2007,

Penelitian Hukum Normatif, Suatu

Tinjauan Singkat, Jakarta, Rajawali.

Sokolski, Henry D. 2010, Reviewing the

Nuclear Nonproliferation Treaty, Pennsylvenia, Strategic Studies

Institute, U.S. Army War College.

Vyas, Utpal et. al. 2015, The North Korea

Crisis and Regional Responses, Hawai'i, East-West Center.

Zhang, Hui. 2006, "The LWR Provision and the North Korean Nuclear Crisis: A Chinese Perspective", The Project on Managing the Atom, Massachusetts, Belfer Center for Science and International Affairs, Kennedy School of Government, Harvard University.

\section{Legal Instrument:}

The Treaty on the Non-Proliferation of Nuclear Weapons 1968.

\section{Miscellaneous:}

Board of Governors General Conference Report by the Director General of IAEA, GOV/2011/53-GC(55)/24, September $2^{\text {nd }}, 2011$, p. 3 , https://isis-online.org/uploads/isisreports/documents/IAEA_DPRK_2 Sept2011.pdf. , accessed on May $23^{\text {rd }}, 2019$ at 9:00 pm
David Albright, 2015, "North Korean Plutonium and Weapon-Grade Uranium Inventories", Institute for Science and International Security, taken from http://isisonline.org/isis-reports/detail/northkorean-plutonium-and-weapongrade-uranium-inventories accessed on May $17^{\text {th }}, 2019$ at 10 pm.

Nuclear Threat Initiative (NTI), Joint Declaration of South and North Korea on the Denuclearization of the Korean Peninsula, https://www.nti.org/learn/treatiesand-regimes/joint-declarationsouth-and-north-koreadenuclearization-korean-peninsula/, accessed on May $17^{\text {th }}, 2019$ at 7:54 pm

Report, $29^{\text {th }}$ February 1968, Embassy of Hungary in North Korea to the Hungarian Foreign Ministry in 1968.

Six-Point Consensus Reached at Six-Party Talks: Chinese Vice FM, Permanent Mission of the People's Republic of China to the UN, August $29^{\text {th }}, 2019$, taken from http://www.chinaun.org/eng/hyyfy/t29001.html, accessed on May 31 ${ }^{\text {st }}, 2019$ at 12:12 am. 